\title{
Pengaruh Good Governance, Kompetensi SDM dan Sistem Pengendalian Intern pada Kualitas Laporan Keuangan
}

\author{
I Gusti Ayu Gita Saraswati ${ }^{1}$ \\ I Gusti Ayu Nyoman Budiasih ${ }^{2}$
}

${ }^{1,2}$ Fakultas Ekonomi dan Bisnis Universitas Udayana (Unud), Bali, Indonesia e-mail: gitasaraswati49@gmail.com

\begin{abstract}
ABSTRAK
Tujuan dari penelitian ini adalah untuk mengetahui pengaruh good governance, kompetensi SDM serta sistem pengendalian intern pada kualitas laporan keuangan di pemerintah Kota Denpasar. Populasi dari penelitian adalah 36 Organisasi Perangkat Daerah (OPD) Kota Denpasar. nonprobability sampling yaitu sampling jenuh merupakan metode pemilihan sampel yang digunakan, sampel yang didapatkan adalah sejumlah 108 responden.Kuesioner merupakan metode pengumpulan data yang digunakan dalam penelitian ini. Responden kuesioner penelitian ini adalah kepada kepala dinas, kepala sub bagian keuangan dan bendahara. Teknik analisis yang digunakan adalah teknik analisis regresi linier berganda. Berdasarkan hasil analisis data ditemukan bahwa good governance, kompetensi SDM dan sistem pengendalian intern memiliki pengaruhpositif pada kualitas laporan keuangan.

Kata kunci : Kualitas laporan keuangan; good governance; kompetensi sumber daya manusia; sistem pengendalian intern
\end{abstract}

\begin{abstract}
The purpose of this study was to determine the effect of good governance, HR competencies and internal control systems on the quality of financial reports in the Denpasar City government. The population of the study was 36 Regional Organizations (OPD) of Denpasar City. nonprobability sampling, which is saturated sampling, is a method of selecting samples used, the sample obtained is 108 respondents. Questionnaire is a data collection method used in this study. Respondents to this research questionnaire were to the head of department, head of the sub-section of finance and treasurer. The analysis technique used is multiple linear regression analysis techniques. Based on the results of data analysis it was found that good governance, HR competence and internal control systems had a positive influence on the quality of financial statements.

Keywords: Financial report quality; good governance; human resource competence; internal control system
\end{abstract}

\section{PENDAHULUAN}

Penyajian laporan keuangan yang berkualitas, dapat dipertanggungjawabkan serta disajikan dengan tepat waktu merupakan kewajiban dari Pemerintah daerah dimana hal tersebut diatur dalam Standar Akuntansi Pemerintah (SAP). SAP menjelaskan mengenai karakteristik dari laporan keuangan yang berkualitas. Karakteristik tersebut adalah laporan keuangan haruslah relevan, andal, dapat 
I Gusti Ayu Gita Saraswati dan I Gusti Ayu Nyoman Budiasih. Pengaruh ...

dibandingkan, serta dapat dipahami sesuai dengan PP Nomor 71 Tahun 2010 tentang Standar Akuntansi Pemerintah (SAP). Selain dari aturan yang diatur dalam SAP, pendapat dari Badan Pemeriksa Keuangan (BPK) juga dapat menjadi acuan dari laporan keuangan yang berkualitas.

Tabel 1.

Laporan Hasil Pemeriksaan Keuangan

\begin{tabular}{lllllll}
\hline Entitas & 2012 & 2013 & 2014 & 2015 & 2016 & 2017 \\
\hline Prov. Bali & WDP & WTP DPP & WTP & WTP & WTP & WTP \\
Kab. Badung & WTP & TW & WTP & WTP & WTP & WTP \\
Kab. Bangli & WDP & TMP & WDP & WDP & WTP & WTP \\
Kab. Buleleng & WDP & WDP & WTP & WTP & WTP & WTP \\
Kab. Gianyar & WDP & WDP & WTP & WTP & WTP & WTP \\
Kab. Jembrana & WDP & WDP & WTP & WTP & WTP & WTP \\
Kab. Karangasem & WDP & WDP & WDP & WTP & WTP & WTP \\
Kab. Klungkung & WDP & WDP & WDP & WTP & WTP & WTP \\
Kab. Tabanan & TMP & WDP & WTP & WTP & WTP & WTP \\
Kota Denpasar & WTP DPP & WTP & WTP & WTP & WTP & WTP \\
\hline Sumber: BPK RI, 2018 & & & & & &
\end{tabular}

Berdasarkan Tabel 1 menunjukkan penilaian dari BPK tahun 2018 untuk laporan keuangan pemerintah Kota Denpasar dalam penilaian enam tahun terakhir (2012-2017) mendapatkan opini Wajar Tanpa Pengecualian (WTP). Laporan keuangan yang disajikan oleh instansi sudah sesuai dengan aturan yang berlaku yaitu Standar Akuntansi Pemerintah atau SAP. Selain telah sesuai dengan SAP laporan keuangan yang disajikan juga dapat diandalkan serta disajikan dengan tepat waktu. Opini WTP yang diberikan oleh BPK menunjukkan bahwa laporan keuangan sudah baik tapi BPK masih menemukan menemukan bahwa Pemerintah Kota Denpasar tidak patuh terhadap peraturan perundang-undangan, yaitu terdapat pengelolaan pendapatan tidak sesuai ketentuan dan terdapat pengelolaan belanja daerah yang tidak sesuai ketentuan (suaradewata.com, 2018).

Masyarakat menuntut adanya peningkatan transparasi dan konsistensi dari laporan keuangan yang dihasilkan (Spathis et al,2002). Dengan diterapkannya 
good governance pada organisasi sektor pubik masyarakat berharap laporan keuangan yang disajikan menjadi lebih berkualitas.

Hasil penelitian Anggreni $d k k,(2018)$ menemukan bahwa pemerintah berupaya untuk menghasilkan laporan keuangan yang berkualitas dengan meningkatkan sumber daya manusia yang lebih spesifiknya yaitu SDM di bidang akuntansi. Dengan meningkatnya kemampuan SDM akuntansi maka akan dapat mengelola keuangan daerah secara efektif. Kompetensi sumber daya manusia adalah kemampuan untuk melaksanakan fungsi-fungsi untuk mencapai tujuannya secara efektif dan efisien (Ihsanti, 2014).

Selain melakukan peningkatan terhadap SDM, Sistem Pengendalian Intern atau SPI juga menjadi salah satu faktor yang dapat mempengaruhi kualitas dari laporan keuangan. Hasil penelitian Trisnawati dan Wiratmaja, (2018) menemukan bahwa organisasi belum melakukan pemisahan tugas dengan baik sehingga hal tersebut berpengaruh pada kualitas dari laporan keuangan.

Teori agensi menjelaskan hubungan antara agent (pihak manajemen suatu perusahaan) dengan principal (pemilik). Agent merupakan pihak yang diberi wewenang oleh principal. Principal akan mengevaluasi kinerja dari agent. Teori agensi dalam wujud nyata merupakan kontrak kerja antara agent dan principal yang mengatur mengenai hak dan kewajiban masing-masing. Agent disini berkewajiban bekerja untuk kepentingan principal dan principal berkewajiban untuk memberikan reward dari hasil kerja agent yang memuaskan. (Jensen \& Meckling, 1976). 
I Gusti Ayu Gita Saraswati dan I Gusti Ayu Nyoman Budiasih. Pengaruh ...

Melakukan pengendalian terhadap perilaku manusia melalui aturan merupakan pengertian dari regulasi(Darmiari \& Ulupui, 2014). Teori regulasi memiliki peran yaitu memberikan informasi yang diperlukan dan dapat dipercaya serta dapat digunakan oleh stakeholder(Rudy, 2013).

Teori kepatuhan telah diteliti pada ilmu-ilmu sosial khususnya di bidang psikologis dan sosiologi yang lebih menekankan pada pentingnya proses sosialisasi dalam mempengaruhi perilaku kepatuhan seorang individu. Terdapat dua perspektif mengenai kepatuhan yaitu instrumental dan normatif.

Catatan informasi dari entitas yang berisi gambaran dari keadaan keuangan entitas dan segala transaksi yang dilakukan oleh entitas tersebut selama suatu periode akuntansi disebut dengan laporan keuangan (Sukmaningrum, 2012).Stakeholdersmenggunakan informasi dalam laporan keuangan sebagai dasar dalam pengambilan keputusan(Bakar \& Saleh, 2011).

Karakteristik laporan keuangan pemerintah berdasarkan PP Nomor 71 Tahun 2010 antara lain yang pertama adalah relevan, dimana laporan keuangan harus berisi informasi yang dapat digunakan untuk pengambilan keputusan. Laporan keuangan yang relevan memiliki manfaat umpan balik atau feedback value, memiliki manfaat prediktif atau predictive value, tepat waktu atau timeliness dan lengkap. Feedback value adalah informasi yang terdapat di dalam laporan keuangan dapat digunakan untuk menjelaskan ataupun mengoreksi di masa yang lalu. Predictive value adalah informasi yang terdapat di dalam laporan keuangan dapat digunakan untuk memprediksi masa yang akan datang. Timeliness 
adalah laporan keuangan disajikan pada waktu yang tepat sesuai dengan kebutuhan pengguna laporan keuangan.

Laporan keuangan yang lengkap yaitu laporan keuangan berisi segala informasi yang diperlukan oleh pengguna yang kemudian dapat digunakan sebagai dasar dari pengambilan sebuah keputusan. Karakteristik laporan keuangan yang kedua adalah andal. Laporan keuangan yang andal adalah laporan keuangan yang tidak menyimpang, dapat dipercaya, bebas dari salah saji material, informasi yang berisi didalamnya jujur sesuai fakta yang ada dan dapat diverifikasi.

Karakteristik yang ketiga adalah laporan keuangan harus dapat dibandingkan. Dapat dibandingkan disini dimaksud bahwa informasi dalam laporan keuangan dapat dibandingkan dengan laporan keuangan periode sebelumnya maupun dibandingkan dengan laporan keuangan organisasi lain.Karakteristik terakhir adalah informasi dalam laporan keuangan haruslah bisa dimengerti isinya. Informasi di dalam laporan keuangan harus bisa dengan mudah dimengerti oleh pihak yang menggunakan atau memerlukan laporan keuangan.

Untuk menjalankan praktik good governance terdapat pedoman yang diterbitkan oleh KNKG pada tahun 2006. Prinsip-prinsip yang dipaparkan dalam KNKG tersebut meliputi pertama transparansi atau Transparancy.Perusahaan harus bisa mengungkapkan seluruh informasi yang diperlukan oleh pengguna laporan keuangan tanpa ada yang ditutup-tutupi. Informasi yang disediakan tidak hanya berdasar kepada peraturan perundang-undangan namun juga harus dapat memenuhi kebutuhan dari pengguna laporan keuangan. 
I Gusti Ayu Gita Saraswati dan I Gusti Ayu Nyoman Budiasih. Pengaruh ...

Dalam laporan keuangan informasi yang terdapat didalamnya haruslah relevan dan mudah untuk dipahami oleh pemangku kepentingan.Dengan adanya keterbukaan oleh instansi kepada pemangku kepentingan, instansi dianggap telah memenuhi salah satu tanggungjawabnya yaitu menyediakan informasi yang diperlukan dalam pengambilan keputusan bagi pengguna laporan keuangan.

Prinsip yang kedua adalah akuntabilitas atau Accountability, pertanggungjawaban atas segala kinerja yang dilakukan harus dapat dilakukan oleh perusahaan. Pertanggungjawaban tersebut harus dilakukan secara terbuka atau transparan dan secara wajar. Dengan adanya pertanggungjawaban secara terbuka dan wajar maka perusahaan akan dituntut untuk menjalankan segala aktivitasnya secara benar dan tetap memikirkan kepentingan stakeholders.

Prinsip yang ketiga adalah responsibilitas atau Responsibility, pertanggungjawaban dari perusahaan terhadap masyarakat dan lingkungan harus dilakukan agar usaha yang dilakukan oleh perusahaan dpat dilakukan dalam jangka panjang dan mendapat pengakuan sebagai good corporate citizen. Keempat independensi atau Independency, pengelolaan perusahaan harus dilakukan secara independent atau mandiri. Hal ini dilakukan untuk menghindari adanya intervensi dari pihak lain. Terakhir kewajaran atau Fairness, asas kewajaran dan kesetaraan untuk kepentingan pemegang saham maupun pemangku kepentingan perlu diperhatikan dalam melakukan segala kegiatan.

Kompetensi merupakan suatu karakteristik dan seseorang yang memiliki keterampilan, pengetahuan, dan kemampuan untuk melaksanakan suatu pekerjaan (Hevesi, 2005). Perusahaan tentu memiliki tujuan yang ingin dicapai. Dalam 
proses pencapaian tujuan tersebut dapat dipengaruhi oleh banyak faktor yang salah satunya adalah kompetensi dari SDM perusahaan tersebut. Kompetensi SDM akan sangat mempengaruhi perusahaan dalam mencapai tujuan yang telah ditetapkan karena SDM dengan kualitas yang baik akan membantu perusahaan mencapai tujuan yang ditetapkan dengan lebih efisien dan efektif.

SDM dengan kualitas yang kurang cenderung akan menghambat perkembangan perusahaan tersebut maka tujuan yang telah ditetapkan oleh perusahaan akan lebih sulit untuk dicapai. SDM dengan kualitas yang baik dapat dinilai dari pengetahuan dan keterampilan yang dimiliki. SDM dengan keterampilan dan pengetahuan yang baik akan lebih produktif karena mereka akan memanfaatkan keterampilan dan pengetahuan yang mereka miliki untuk menyelesaikan tanggung jawab yang diberikan.

Dengan adanya SDM yang berkualitas, tentunya akan mampu mempengaruhi kualitas informasi akuntansi pada pelaporan keuangan. Kompetensi SDM dalam hal ini yaitu SDM yang memiliki kualitas yang baik, memiliki pemahaman mengenai akuntansi dan keuangan serta memiliki latar belakang pendidikan yang sesuai dengan tanggungjawabnya yang dalam hal ini adalah akuntansi dan keuangan, akan berdampak pada pengelolaan keuangan yang baik.

SPI dari pemerintahan memiliki unsur-unsur yang pertama adalah pimpinan instansi harus dapat menciptakan lingkungan pengendalian. Lingkungan pengendalian yang dimaksud adalah dalam lingkungan kerja haruslah tercipta aura positif serta kondusif yang memadai untuk diterapkannya SPI. Kedua adalah 
I Gusti Ayu Gita Saraswati dan I Gusti Ayu Nyoman Budiasih. Pengaruh ...

pimpinan instansi wajib melakukan penilaian risiko. Penilaian risiko yang wajib dilakukan oleh pimpinan instansi yaitu pimpinan harus mengidentifikasi kemungkinan risiko yang akan terjadi serta pimpinan instansi harus menganalisis risiko yang akan terjadi tersebut agar mendapatkan solusi dari risiko yang akan terjadi.

Sebelum melakukan identifikasi dan menganalisis risiko, pimpinan instansi haruslah menetapkan tujuan dari instansi yang dipimpinnya. Tujuan tersebut harus ditetapkan secara terperinci. Ketiga adalah pimpinan instansi harus melakukan kegiatan pengendalian yaitu melakukan pengendalian terhadap instansi sesuai dengan keadaan instansi yang dipimpinnya. Keempat adalah pimpinaninstansi harus dapat memberikan informasi dengan berkomunikasi dengan anggota instansi dengan baik.Pimpinan instansi pemerintah harus mengkomunikasikan segala bentuk informasi. Kelima adalah pemantauan pengendalian intern dimana pimpinan melakukan pemantauan terhadap SPI dalam bentuk sebuah evaluasi.

Beberapa penelitian telah dilakukan terkait hubungan good governance pada kualitas laporan keuangan. Penelitian Anggreni $d k k$, (2018) menunjukkan bahwa good governance memiliki pengaruh yang positif pada kualitas laporan keuangan. Kantu $d k k$, (2015) menunjukkan bahwa good governance berpengaruh positif dan signifikan terhadap kualitas laporan keuangan. Sejalan dengan penelitian Yang dan Suartana, (2017) menunjukkan bahwa good governance berpengaruh positif dan signifikan pada kinerja pemerintah daerah. Good governance yang diterapkan dengan baik maka akan berdampak dengan baiknya pula kualitas dari laporan keuangan yang dihasilkan. Hipotesis satu dari penelitian ini adalah: 
$\mathrm{H}_{1}$ : Good governance berpengaruh positif pada kualitas laporan keuangan di pemerintah Kota Denpasar

Beberapa penelitian telah dilakukan terkait hubungan kompetensi sumber daya manusia pada kualitas laporan keuangan. Penelitian Kiranayanti dan Erawati, (2016) menemukan bahwa kompetensi SDM memiliki pengaruh yangsignifikan pada kualitas laporan keuangan. Agung, (2018) dan Pratiwi, (2018) dalam penelitiannya juga menemukan bahwa kompetensi SDM berpengaruh signifikan pada kualitas laporan keuangan.

Untuk menghasilkan laporan keuangan yang berkualitas diperlukan kemampuan yang cukup dari SDM. Kemampuan pemahaman yang baik mengenai ilmu akuntasi akan meminimalisir terjadinya kesalahan yang mengakibatkan kekeliruan dalam pembuatan laporan keuangan. Kualitas laporan keuangan akan meningkat ketika sumber daya manusia yang dimiliki oleh instansi memiliki kompetensi yang dinilai cukup baik. Hipotesis dua penelitian ini adalah:

$\mathrm{H}_{2}$ : Kompetensi sumber daya manusia berpengaruh positif pada kualitas laporan keuangan di pemerintah Kota Denpasar.

Dalam penelitian Mahaputra dan Putra, (2014), Nurillah, (2014), dan Trisnawati dan Wiratmaja, (2018) menunjukkan bahwa sistem pengendalian intern berpengaruh positif dan signifikan pada kualitas laporan keuangan. Pengendalian intern merupakan cara yang dapat memberikan arahan serta mengawasi sumber daya suatu organisasi serta memiliki peran dalam pencegahan penggelapan atau fraud dan melindungi sumber daya organisasi. Hipotesis tiga untuk penelitian ini adalah:

$\mathrm{H}_{3}$ : Sistem pengendalian intern berpengaruh positif pada kualitas laporan keuangan di pemerintah Kota Denpasar. 


\section{METODE PENELITIAN}

Penelitian ini menggunakan pendekatan kuantitatif yang berbentuk asosiatif.Pendekatan kuantitatif yang bertujuan untuk mengetahui hubungan dari satu variabel atau lebih (Sugiyono, 2017:20). Penelitian ini dilakukan pada pemerintah Kota Denpasar. Pemilihan lokasi tersebut karena hasil dari pemeriksaan Badan Pemeriksa Keuangan (BPK) RI masih ada beberapa kelemahan dan rekomendasi yang harus ditindaklanjuti oleh pemerintah Kota Denpasar sehingga peneliti diasumsikan layak untuk dijadikan lokasi penelitian (suaradewata.com, 2018). Objek penelitian ini yaitu kualitas laporan keuangan di pemerintah Kota Denpasar.

Variabel terikat atau dependent variable yaitu variabel yang dipengaruhi atau yang menjadi akibat, karena adanya variabel bebas (independent variable) Variabel terikat dalam penelitian ini adalah kualitas laporan keuangan (Y).Variabel bebas atau independent variable yaitu variabel yang menjadi sebab perubahan atau yang mempengaruhi variabel terikat (dependent variabel). Variabel bebas dalam penelitian ini adalah good governance $\left(\mathrm{X}_{1}\right)$, kompetensi sumber daya manusia $\left(\mathrm{X}_{2}\right)$ dan sistem pengendalian intern $\left(\mathrm{X}_{3}\right)$.

Variabel kualitas laporan keuangan pemerintah daerah diukur dengan menggunakan kuesioner yang diadopsi dari penelitian Anggreni $d k k$, (2018). Laporan keuangan yang lengkap yaitu laporan keuangan berisi segala informasi yang diperlukan oleh pengguna yang kemudian dapat digunakan sebagai dasar dari pengambilan sebuah keputusan. Karakteristik laporan keuangan yang kedua adalah andal. Laporan keuangan yang andal adalah laporan keuangan yang tidak 
menyimpang, dapat dipercaya, bebas dari salah saji material, informasi yang berisi didalamnya jujur sesuai fakta yang ada dan dapat diverifikasiIndikator dari kuesioner kualitas laporan keuangan, yaitu yang pertama adalah aktivitas keuangan dimasa lalu, indikator yang kedua yaitu memprediksi masa yang akan datang, indikator yang ketiga ketepatwaktuan atau timeliness, indikator yang keempat adalah pengambilan keputusan, indikator yang kelima yaitu disajikan wajar dan jujur, indikator yang keenam adalah informasi dapat dibandingkan, dan indikator yang terakhir yaitu informasi dalam laporan keuangan dapat dipahami sesuai Standar Akuntansi Pemerintah (SAP).

Pengukuran penerapan good governance diadopsi dari penelitian Anggreni $d k k$, (2018). Untuk menjalankan praktik good governance terdapat pedoman yang diterbitkan oleh KNKG pada tahun 2006. Prinsip-prinsip yang dipaparkan dalam KNKG tersebut meliputi pertama transparansi atau Transparancy.Perusahaan harus bisa mengungkapkan seluruh informasi yang diperlukan oleh pengguna laporan keuangan tanpa ada yang ditutup-tutupi. Informasi yang disediakan tidak hanya berdasar kepada peraturan perundang-undangan namun juga harus dapat memenuhi kebutuhan dari pengguna laporan keuangan. Indikator dari kuesioner good governance yang terdiri dari sembilan indikator yaitu pertama partisipasi, kedua taat akan hukum, ketiga transparansi atau keterbukaan, keempat daya tanggap, kelima kesetaraan, keenam efektifitas dan efisiensi, ketujuh akuntabilitas, kedelapan visi strategis, dan terakhir orientasi konsensus.

Pengukuran kompetensi sumber daya manusia diadopsi dari penelitian Anggreni $d k k$, (2018). Indikator dari kuesioner kompetensi sumber daya manusia, 
I Gusti Ayu Gita Saraswati dan I Gusti Ayu Nyoman Budiasih. Pengaruh ...

yaitu yang pertama adalah bagaimana SDM memahami mengenai akuntansi, yang kedua adalah kualitas dari SDM, indikator yang ketiga adalah sumber daya yang memadai, yang keempat adalah pengetahuan mengenai peran dan tanggung jawab, yang kelima adalah pengadaan pelatihan keahlian dalam tugas, yang keenam adalah sosialisasi peraturan baru, dan terakhir adalah bagaimana pemahaman tentang struktur organisasi.

Pengukuran sistem pengendalian intern diadopsi dari penelitianShintia \& Erawati, (2017). SPI dari pemerintahan memiliki unsur-unsur yang pertama adalah pimpinan instansi harus dapat menciptakan lingkungan pengendalian. Lingkungan pengendalian yang dimaksud adalah dalam lingkungan kerja haruslah tercipta aura positif serta kondusif yang memadai untuk diterapkannya SPI. Kedua adalah pimpinan instansi wajib melakukan penilaian risiko. Penilaian risiko yang wajib dilakukan oleh pimpinan instansi yaitu pimpinan harus mengidentifikasi kemungkinan risiko yang akan terjadi serta pimpinan instansi harus menganalisis risiko yang akan terjadi tersebut agar mendapatkan solusi dari risiko yang akan terjadi. Indikator dari kuesioner sistem pengendalian intern, yaitu: lingkungan pengendalian, penilaian risiko, informasi dan komunikasi, dan pemantauan.

Populasi yang dipilih untuk penelitian ini adalah pengelola unit kerja bagian keuangan di 36 Organisasi Perangkat Daerah (OPD) di pemerintah Kota Denpasar. Pengelola unit kerja bagian keuangan terdiri dari kepala dinas, kepala sub bagian dan bendahara. Populasi dalam penelitian ini yaitu 36 OPD $\times 3$ orang berjumlah 108 orang.Teknik penentuan sampel dalam penelitian ini adalah nonprobability sampling yaitu dengan pendekatan sampling jenuh. Sampel dalam 
penelitian ini adalah sebanyak 108 orang. Teknik penentuan sampel yang digunakan adalah pendekatan sampling jenuh. Sampling jenuh yaitu dimana seluruh populasi menjadi anggota sampel

Penelitian ini menggunakan jenis data kuantitatif. Data kuantitatif adalah data yang berbentuk kata, atau data kualitatif yang diangkakan. (Sugiyono, 2017:15). Data kuantitatif dalam penelitian ini adalah jawaban kuesioner dari responden yang diukur dengan menggunakan skor dari skala likert.Data primer dalam penelitian ini adalah jawaban dari responden yang atas serangkaian pernyataan kuesioner yang disebarkan. Data sekunder dalam penelitian ini adalah daftar Organisasi Perangkat Daerah (OPD) di pemerintah Kota Denpasar.

Metode pengumpulan data yang digunakan dalam penelitian ini adalah kuesioner. Data diperoleh dengan menggunakan kuesioner yang dibagikan secara langsung kepada responden. Hasil kuesioner menggunakan skala likert dengan skala 4 poin, hal ini dimaksudkan untuk menghindari adanya kecenderungan responden yang memilih jawaban netral jika menggunakan skala 5 poin. Dalam penelitian ini, jawaban responden akan diukur dengan menggunakan skala likert yang dimulai dari poin 1 sangat tidak setuju (STS), poin 2 tidak setuju (TS), poin 3 setuju (S), dan poin 4 sangat setuju (SS).Data berfungsi sebagai alat pembuktian hipotesis dan merupakan variabel yang diteliti.Oleh karena itu data merupakan hal yang sangat penting karena kebenaran data sangat menentukan kualitas hasil suatu penelitian.Kebenaran data tergantung pada instrumen yang dipergunakan dalam mengumpulkan data. Adapun syarat dari instrumen yang baik adalah harus valid dan reliabel. 
I Gusti Ayu Gita Saraswati dan I Gusti Ayu Nyoman Budiasih. Pengaruh ...

\section{HASIL DAN PEMBAHASAN}

Kuesioner dapat dikatakan valid jika nilai pearson correlation terhadap total skor lebih besar dari 0,3 . Seluruh indikator pernyataan dalam kuesioner dengan variabel good governance $\left(\mathrm{X}_{1}\right)$, kompetensi SDM $\left(\mathrm{X}_{2}\right)$ dan SPI $\left(\mathrm{X}_{3}\right)$ memiliki nilai pearson correlation yang lebih besar dari 0,03 , maka dapat disimpulkan bahwa instrumen kuesioner tersebut valid.

Uji reliabilitas dilakukan dengan melihat hasil dari Cronbach's Alpha Coefficient. Berikut dalam Tabel 2 disajikan hasil dari uji reliabilitas.

Tabel 2.

Hasil Uji Reliabilitas

\begin{tabular}{lcc}
\hline \multicolumn{1}{c}{ Variabel } & Cronbach's Alpha & Keterangan \\
\hline Good Governance $\left(\mathrm{X}_{1}\right)$ & 0,887 & Reliabel \\
Kompetensi SDM $\left(\mathrm{X}_{2}\right)$ & 0,887 & Reliabel \\
Sistem Pengendalian Intern $\left(\mathrm{X}_{3}\right)$ & 0,898 & Reliabel \\
Kualitas Laporan Keuangan $(\mathrm{Y})$ & 0,921 & Reliabel \\
\hline
\end{tabular}

Sumber: Data diolah, 2019

Setelah melakukan uji reliabiliitas didapatkan hasil bahwa semua variabel yang digunakan dalam penelitian ini memiliki nilai Cronbach's Alpha lebih besar dari 0,60 , oleh karena itu instrumen yang digunakan dalam penelitian ini adalah reliabel.

Hasil statistik deskriptif pada penelitian ini yang dapat dilihat pada Tabel 3 sebagai berikut.

Tabel 3.

Hasil Statistik Deskriptif

\begin{tabular}{lccccc}
\hline \multicolumn{1}{c}{ Variabel } & $\mathrm{N}$ & Min. & Max. & Mean & $\begin{array}{c}\text { Std. } \\
\text { Deviation }\end{array}$ \\
\hline Good Governance $\left(\mathrm{X}_{1}\right)$ & 108 & 35 & 48 & 40,56 & 4,161 \\
Kompetensi SDM $\left(\mathrm{X}_{2}\right)$ & 108 & 24 & 44 & 3553 & 4,093 \\
Sistem Pengendalian Intern $\left(\mathrm{X}_{3}\right)$ & 108 & 36 & 56 & 46,07 & 4,394 \\
Kualitas Laporan Keuangan $(\mathrm{Y})$ & 108 & 31 & 48 & 39,66 & 4,208 \\
\hline
\end{tabular}

Sumber: Data diolah, 2019 
Pengujian asumsi klasik digunakan sebelum melakukan analisis dengan teknik regresi, maka model persamaan regresi harus melalui uji asumsi klasik.Uji normalitas ini bertujuan untuk mengetahui apakah residual dari model regresi yang dibuat berdistribusi normal atau tidak. Dalam penelitian ini uji normalitas dilakukan dengan menguji normalitas residual dengan menggunakan uji Kolmogrov Smirnov dengan melihat sig (2-tailed).Apabila Asymp. Sig (2-tailed) lebih besar dari level of significant yang dipakai $(0,05)$, maka residu dari persamaan regresi dapat dikatakan berdistribusi normal. Adapun hasil uji normalitas pada penelitian ini yang dapat dilihat pada Tabel 4 sebagai berikut.

Tabel 4. Hasil Uji Normalitas

\begin{tabular}{lc}
\hline & Unstandardized Residual \\
\hline Kolmogrov-Smirnov Z & 0,836 \\
Asymp. Sig (2-tailed) & 0,487 \\
\hline Sumber: Data diolah, 2019 &
\end{tabular}

Setelah dilakukan pengujian normalitas ditemukan bahwa nilai Asymp. Sig (2-tailed) yaitu 0,487 lebih besar dari 0,05, maka model regresi yang digunakan dalam penelitian ini berdistribusi normal.

Uji asumsi klasik selanjutnya yang digunakan dalam penelitian ini adalah uji multikolinieritas. Uji ini dilakukan untuk mengetahui korelasi antar variabel bebas dimana dalam penelitian ini terdapat tiga variabel bebas. Cara pertama untuk mengetahui keterdapatan multikolinieritas dalam penelitian ini adalah dengan melihat nilai tolerancenya. Untuk menghindari multikolinieritas diperlukan nilai tolerance yang melebihi 0,1 atau $10 \%$ dan yang kedua adalah dengan melihat nilaiVIF. Diperlukan nilai VIF yang kurang dari 10 untuk 
menghindari dari adanya multikolinieritas. Adapun hasil uji multikolonieritas pada penelitian ini yang dapat dilihat pada Tabel 5 sebagai berikut.

Tabel 5. Hasil Uji Multikoloniearitas

\begin{tabular}{|c|c|c|}
\hline Variabel & Tolerance & VIF \\
\hline Good Governance $\left(\mathrm{X}_{1}\right)$ & 0,483 & 2,072 \\
\hline Kompetensi SDM $\left(\mathrm{X}_{2}\right)$ & 0,541 & 1,849 \\
\hline Sistem Pengendalian Intern $\left(\mathrm{X}_{3}\right)$ & 0,358 & 2,794 \\
\hline
\end{tabular}

Sumber: Data diolah, 2019

Berdasarkan Tabel 5 menunjukkan bahwa nilai tolerance masing-masing variabel lebih besar dari 0,1 dan nilai VIF lebih kecil dari 10, sehingga dapat dinyatakan bahwa dalam kedua model regresi tidak terjadi multikolonieritas.

Uji asumsi klasik selanjutnya adalah uji heteroskedastisitas. Agar terhindar dari masalah heteroskedastisitas, maka diperlukan tingkat signifikansi yang melebihi 0,05. Adapun hasil uji heteroskedastisitas pada penelitian ini yang dapat dilihat pada Tabel 6 sebagai berikut.

Tabel 6.

Hasil Uji Heteroskedastisitas

\begin{tabular}{lc}
\hline \multicolumn{1}{c}{ Variabel } & Sig. \\
\hline Good Governance $\left(\mathrm{X}_{1}\right)$ & 0,741 \\
Kompetensi SDM $\left(\mathrm{X}_{2}\right)$ & 0,161 \\
Sistem Pengendalian Intern $\left(\mathrm{X}_{3}\right)$ & 0,765 \\
\hline Sumber: Data diolah, 2019 &
\end{tabular}

Dalam Tabel 6 dapat dilihat bahwa nilai signifikan dari semua variabel yang digunakan dalam penelitian ini memiliki nilai yang melebihi 0,05 yang berarti model regresi yang digunakan dalam penelitian ini bebas dari gejala heteroskedastisitas.

Analisis linier berganda digunakan untuk mengetahui pengaruh variabel bebas pada variabel terikat. Statitical Product and Service Solution(SPSS) 
ISSN: 2302-8556

E-Jurnal Akuntansi Universitas Udayana

Vol.27.3.Juni (2019): 2268-2292

digunakan untuk melakukan analisis ini. Pada Tabel 7 disajikan hasil dari analisis linier berganda

Tabel 7.

Hasil Analisis Regresi Linier Berganda

\begin{tabular}{|c|c|c|c|c|c|}
\hline \multirow[b]{2}{*}{ Variabel } & \multicolumn{2}{|c|}{$\begin{array}{c}\text { Unstandardized } \\
\text { Coefficients }\end{array}$} & \multicolumn{2}{|c|}{$\begin{array}{l}\text { Standardized } \\
\text { Coefficients }\end{array}$} & \multirow[b]{2}{*}{ Sig. } \\
\hline & $\mathrm{B}$ & Std. Error & Beta & $\mathrm{t}$ & \\
\hline (Constant) & $-1,575$ & 2,187 & & $0,720^{-}$ & 0,473 \\
\hline Good Governance $\left(\mathrm{X}_{1}\right)$ & 0,353 & 0,068 & 0,349 & 5,211 & 0,000 \\
\hline Kompetensi SDM $\left(\mathrm{X}_{2}\right)$ & 0,184 & 0,065 & 0,179 & 2,836 & 0,005 \\
\hline Sistem Pengendalian Intern $\left(\mathrm{X}_{3}\right)$ & 0,442 & 0,074 & 0,462 & 5,944 & 0,000 \\
\hline Adjusted $R^{2}$ & & & & & 0,769 \\
\hline F Hitung & & & & & 119,538 \\
\hline Sig. F & & & & & 0.000 \\
\hline
\end{tabular}

Berdasarkan hasil analisis regresi linier berganda seperti yang disajikan pada

Tabel 7, maka dapat dibuat persamaan regresi sebagai berikut.

$$
Y=-1,575+0,353 X_{1}+0,184 X_{2}+0,442 X_{3}
$$

Berdasarkan persamaan diatas, dapat dijelaskan bahwa nilai konstanta sebesar -1,575 menunjukkan bahwa apabila variabel good governance $\left(\mathrm{X}_{1}\right)$, kompetensi sumber daya manusia $\left(\mathrm{X}_{2}\right)$, dan sistem pengendalian intern $\left(\mathrm{X}_{3}\right)$ sama dengan nol, maka nilai dari kualitas laporan keuangan turun sebesar 157,5 persen.

Nilai B dari variabel good governance yaitu 0,353, hal ini menunjukkan bahwa good governance mempunyai pengaruh searah pada kualitas laporan keuangan dan apabila good governance naik 1 persen maka kualitas laporan keuangan akan meningkat sebesar 35,3 persen dengan asumsi bahwa variabel independen lainnya konstan.

Nilai koefisien regresi dari variabel kompetensi SDM yaitu 0,184, hal ini menunjukkan bahwa kompetensi sumber daya manusia mempunyai pengaruh searah pada kualitas laporan keuangan dan apabila kompetensi sumber daya 
I Gusti Ayu Gita Saraswati dan I Gusti Ayu Nyoman Budiasih. Pengaruh ...

manusia naik 1 persen maka kualitas laporan keuangan akan meningkat sebesar 18,4 persen dengan asumsi variabel independen lainnya konstan.

Nilai koefisien regresi dari variabel sistem pengendalian intern sebesar 0,442, hal ini menunjukkan bahwa sistem pengendalian intern mempunyai pengaruh searah pada kualitas laporan keuangan dan apabila sistem pengendalian intern naik 1 persen maka kualitas laporan keuangan akan meningkat sebesar 44,2 persen dengan asumsi variabel independen lainnya konstan.

Disebutkan pada Tabel 7Adjusted $R^{2}$ untuk kualitas laporan keuangan adalah sebesar 0,769. Nilai 0,769 memiliki arti sebesar 76,9\% variabel kualitas laporan keuangan dapat dijelaskan oleh variasi good governance, kompetensi SDM dan SPI, sedangkan 23,1\% dijelaskan oleh variabel lain diluar model yang digunakan dalam penelitian ini. Setelah dilakukannya uji F, ditemukan bahwa nilai signifikansi dari variabel kualitas laporan keuangan yaitu 0,000 yang lebih rendah dari 0,05 . Hal ini berarti model yang dipilih adalah layak untuk digunakan dalam penelitian ini.

Hasil dari uji t yaitu pada Tabel 7 menunjukkan bahwa tingkat signifikansi uji t satu sisi variabel good governance adalah sebesar 0,000 yang lebih kecil dari 0,05. Hal tersebut menunjukkan bahwa $\mathrm{H}_{1}$ diterima, yang berarti penerapan good governance berperngaruh pada kualitas laporan keuangan di pemerintah Kota Denpasar atau semakin baik penerapan good governance akan meningkatkan kualitas laporan keuangan di pemerintah Kota Denpasar.Berpengaruh positif disini memiliki arti jika penerapan good governance yang diterapkan oleh OPD baik maka kualitas dari laporan keuangan yang dihasilkan juga akan meningkat. 
OPD yang menerapkan good governance dalam melakukan pengelolaan keuangan cenderung akan memiliki kualitas laporan keuangan yang baik sehinggaa dapat dipertanggungjawabkan terhadap pemerintah pusat serta dapat dipertanggungjawabkan terhadap masyarakat.

Hasil penelitian ini sesuai dengan penelitian yang dilakukan oleh Anggreni $d k k$, (2018). Dalam penelitiannya ditemukan bahwa instansi yang menerapkan good governance untuk tujuan keterbukaan terhadap masyarakat dan bertanggungjawab terhadap masyarakat. Dengan diterapkannya good governance pengelolaan keuangan dapat lebih taat terhadap aturan yang ditetapkan, memiliki prosedur yang jelas dan dapat dipertanggungjawabkan. Kantu $d k k$, (2015) yang membuktikan secara empiris bahwa instansi yang memberlakukan good governance maka akan membawa dampak positif bagi instansi. Sejalan dengan penelitian Yang\& Suartana, (2017) menunjukkan bahwa good governance memiliki pengaruh positif pada kinerja pemerintah daerah.

Teori keagenan mendukung hasil dari penelitian ini dimana dalam teori keagenan dijelaskan bahwa agent yang dalam penelitian ini adalah pemerintah harus dapat memberikan pertanggungjawaban kepada principal yang dalam penelitian ini adalah masyarakat. Bentuk pertanggungjawaban ini merupakan kewajiban dari agent atas segala kegiatan yang telah dilakukan atas kepentingan principal. Penerapan good governance yang dilakukan secara baik dan konsisten akan membuat segala kegiatan di pemerintah daerah akan berjalan secara efektif dan efisien, hal ini menunjukkan bahwa pengungkapan informasi secara tepat waktu dan akurat akan membawa dampak yang positif terhadap kualitas laporan 
I Gusti Ayu Gita Saraswati dan I Gusti Ayu Nyoman Budiasih. Pengaruh ...

keuangan yaitu meningkatnya kualitas laporan keuangan pemerintah di Kota Denpasar.

Pada Tabel 7 menunjukkan bahwa tingkat signifikan uji t satu sisi variabel kompetensi sumber daya manusia adalah sebesar 0,005 yang lebih kecil dari 0,05. Hal tersebut menunjukkan bahwa $\mathrm{H}_{2}$ diterima, yang berarti kompetensi sumber daya manusia berpengaruh pada kualitas laporan keuangan di pemerintah Kota Denpasar atau semakin tinggi kompetensi sumber daya manusia akan meningkatkan kualitas laporan keuangan di pemerintah Kota Denpasar.Berpengaruh positif disini berarti semakin tinggi kompetensi SDM akan meningkatkan kualitas dari laporan keuangan di pemerintah Kota Denpasar. Begitu pula sebaliknya, semakin rendah kompetensi sumber daya manusia untuk meningkatkan kualitas laporan keuangannya, maka semakin rendah pula kualitas laporan keuangan yang disajikan oleh pemerintah Kota Denpasar. Dengan adanya SDM yang berkualitas, tentunya akan mampu mempengaruhi kualitas informasi akuntansi pada pelaporan keuangan. Kompetensi SDM dalam hal ini yaitu SDM yang memiliki kualitas yang baik, memiliki pemahaman mengenai akuntansi dan keuangan serta memiliki latar belakang pendidikan yang sesuai dengan tanggungjawabnya yang dalam hal ini adalah akuntansi dan keuangan, akan berdampak pada pengelolaan keuangan yang baik.

Hasil penelitian ini sejalan dengan penelitian Kiranayanti\& Erawati, (2016) yang membuktikan secara empiris bahwa kompetensi sumber daya manusia yang tergolong baik bisa dilihat dengan banyaknya pelatihan-pelatihan yang diikuti oleh pegawai. Sejalan dengan penelitian Darmiari\& Ulupui, (2014) dan Pratiwi, 
(2018) menunjukkan bahwa kompetensi sumber daya manusia memiliki pengaruh yang positif pada kualitas laporan keuangan.

Teori regulasi mendukung hasil dari penelitian ini dimana teori regulasi menyatakan bahwa SDM yang diberi wewenang dalam pengelolaan keuangan daerah harus selalu berpedoman pada regulasi dan landasan hukum yang berlaku agar laporan keuangan yang dihasilkan berkualitas. Untuk meningkatkan efektivitas dari pengelolaan keuangan serta peningkatan kualitas laporan keuangan, pemerintah berupaya dengan melakukan peningkatan terhadap kompetensi dari SDM. Sumber daya manusia yang dikelola dengan baik akan menghasilkan sumber daya manusia yang berkompeten dan berkualitas sehingga pencatatan sampai dengan laporan keuangan menjadi semakin baik.

Pada Tabel 7 menunjukkan bahwa tingkat signifikansi uji t satu sisi variabel sistem pengendalian intern adalah sebesar 0,000 yang lebih kecil dari 0,05. Hal tersebut menunjukkan bahwa $\mathrm{H}_{3}$ diterima, yang berarti sistem pengendalian intern berpengaruh pada sistem pengendalian intern di pemerintah Kota Denpasar atau semakin baik sistem pengendalian intern akan semakin baik pula kualitas laporan keuangan di pemerintah Kota Denpasar. Berpengaruh positif disini memiliki arti bahwa dengan adanya pengingkatan SPI akan berdampak pada peningkatan kualitas laporan keuangan yang dihasilkan di pemerintah Kota Denpasar juga akan terjadi peningkatan. Proses yang baik dalam suatu organisasi akan tercipta dengan adanya SPI yang baik juga. Dengan diterapkannya SPI yang baik dan benar maka anggota instansi akan memiliki rasa yakin atas segala aktivitas yang dilakukan bahwa seluruh aktivitas telah sesuai standar yang berlaku. 
I Gusti Ayu Gita Saraswati dan I Gusti Ayu Nyoman Budiasih. Pengaruh ...

SPI dari pemerintahan memiliki unsur-unsur yang pertama adalah pimpinan instansi harus dapat menciptakan lingkungan pengendalian. Lingkungan pengendalian yang dimaksud adalah dalam lingkungan kerja haruslah tercipta aura positif serta kondusif yang memadai untuk diterapkannya SPI. Kedua adalah pimpinan instansi wajib melakukan penilaian risiko. Penilaian risiko yang wajib dilakukan oleh pimpinan instansi yaitu pimpinan harus mengidentifikasi kemungkinan risiko yang akan terjadi serta pimpinan instansi harus menganalisis risiko yang akan terjadi tersebut agar mendapatkan solusi dari risiko yang akan terjadi.

Sebelum melakukan identifikasi dan menganalisis risiko, pimpinan instansi haruslah menetapkan tujuan dari instansi yang dipimpinnya. Tujuan tersebut harus ditetapkan secara terperinci. Ketiga adalah pimpinan instansi harus melakukan kegiatan pengendalian yaitu melakukan pengendalian terhadap instansi sesuai dengan keadaan instansi yang dipimpinnya. Keempat adalah pimpinaninstansi harus dapat memberikan informasi dengan berkomunikasi dengan anggota instansi dengan baik.Pimpinan instansi pemerintah harus mengkomunikasikan segala bentuk informasi. Kelima adalah pemantauan pengendalian intern dimana pimpinan melakukan pemantauan terhadap SPI dalam bentuk sebuah evaluasi.

Sejalan dengan penelitian Shintia\& Erawati, (2017) yang menunjukkan bahwa peningkatkan reliabilitas, objektivitas informasi dan pencegahan inkonsistensi dan memudahkan proses dalam laporan keuangan dapat diperoleh dengan melakukan penerapan SPI yang baik. Sejalan dengan penelitian Mahaputra\& Putra, (2014), Nurillah, (2014), dan Trisnawati \& Wiratmaja, (2018) 
yang menunjukkan bahwa sistem pengendalian intern memiliki pengaruh yang positif pada kualitas laporan keuangan.

Teori kepatuhan mendukung hasil dari penelitian ini dimana teori kepatuhan menyatakan bahwa hubungan antara SPI dengan kualitas laporan keuangan pemerintah daerah dimana pengendalian intern ditunjukkan untuk memberikan keyakinan memadai bahwa laporan keuangan pemerintah daerah telah disajikan sesuai dengan standar akuntansi pemerintah, telah patuh terhadap hukum yang berlaku serta meningkatan kegaiatan operasi secara efektif dan efisien.

\section{SIMPULAN}

Penelitian ini bertujuan untuk mengetahui hubungan antara good governance pada kualitas laporan keuangan, hubungan antara kompetensi SDM pada kualitas laporan keuangan dan hubungan antara sistem pengendalian intern pada kualitas laporan keuangan.

Setelah melakukan analisis data hasil yang didapatkan adalah yang pertama good governance memiliki pengaruh yang positif dan searah pada kualitas laporan keuangan di pemerintah Kota Denpasar yang berarti dengan diterapkannya good governance maka kualitas laporan keuangan akan semakin baik. Yang kedua adalah kompetensi SDMmemiliki pengaruh yang positif dan searah pada kualitas laporan keuangan yang berarti dengan adanya peningkatan kompetensi SDM maka akan terjadi peningkatan pula pada kualitas laporan keuangan. Terakhir SPImemiliki pengaruh yang positif dan searah pada kualitas laporan keuangan 
yang berarti dengan diterapkannya SPI dengan baik maka akan berdampak pada peningkatan kualitas laporan keuangan yang dihasilkan.

\section{REFRENSI}

Agung, Tut Madiguna., \& G. (2018). Analisis Faktor-Faktor yang Mempengaruhi Kualitas Laporan Keuangan Pemerintah Daerah Kabupaten Karangasem. EJurnal Akuntansi Universitas Udayana, 23(2), 1253-1276.

Anggreni, Ni Made Mei., Widanaputra, A.A.G.P., \& Putri, I. G. A. M. A. D. (2018). Pengaruh Good Governance dan Kompetensi Sumber Daya Manusia pada Kualitas Laporan Keuangan di Kota Denpasar. E-Jurnal Akuntansi Universitas Udayana, 22(1), 352-380.

Bakar, Nur Barizah Abu., \& Z. S. (2011). Incentives for Disclosure of Accounting Information in Public Sector: A Literature Survey. International Research Journal of Finance and Economics, (75).

Darmiari, Ni Putu Desy., \& Ulupui, I. G. K. A. (2014). Karakteristik Perusahaan di Bursa Efek Indonesia, Reputasi Kantor Akuntan Publik dan Ketepatwaktuan Pelaporan Keuangan. E-Jurnal Akuntansi Universitas Udayana, 9(1), 38-57.

Hevesi, A. G. (2005). Standards for Internal Control in New York State Government. Www.Osc.State.Ny.Us.

Ihsanti, E. (2014). Pengaruh Kompetensi Sumber Daya Manusia dan Penerapan Sistem Akuntansi Keuangan Daerah Terhadap Kualitas Laporan Keuangan Daerah (Studi Empiris pada SKPD Kab. Lima Puluh Kota). Jurnal Akuntansi Universitas Negeri Padang.

Jensen, Michael C., \& W. H. M. (1976). Theory of The Firm: Managerial Behavior, Agency Cost and Ownership Structure. Journal of Financial Economics, 3, 305-360.

Kantu, Meyi., Sahmin Noholo., \& H. V. M. (2015). Pengaruh Penerapan Good Governance Terhadap Kualitas Laporan Keuangan (Studi Kasus pada Dinas Pendapatan Pengelolaan Keuangan dan Aset Daerah Kota Gorontalo). Jurnal Akuntansi Universitas Negeri Gorontalo, 3(2), 1-13.

Kiranayanti, Ida Ayu Enny., \& Erawati, N. M. A. (2016). Pengaruh Sumber Daya Manusia, Sistem Pengendalian Intern, Pemahaman Basis Akrual Terhadap Kualitas Laporan Keuangan Daerah. E-Jurnal Akuntansi Universitas 
Udayana, 16(2), 1290-1318.

Mahaputra, I Putu Upabayu Rama., \& Putra, I. W. (2014). Analisis Faktor-faktor yang Mempengaruhi Kualitas Informasi Pelaporan Keuangan Pemerintah Daerah. E-Jurnal Akuntansi Universitas Udayana, 8(2), 230-244.

Nurillah, As Syifa., \& D. M. (2014). Pengaruh Kompetensi Sumber Daya Manusia, Penerapan Sistem Akuntansi Keuangan Daerah (SAKD), Pemanfaatan Teknologi Informasi dan Sistem Pengendalian Intern Terhadap Kualitas Laporan Keuangan Pemerintah Daerah (Studi Empiris pada SKPD Kota Depok). Jurnal Akuntansi Universitas Diponegoro, 3(2), 1-13.

Pratiwi, I. (2018). Pengaruh Kompetensi Sumber Daya Manusia dan Penerapan Sistem Akuntansi Keuangan Daerah Terhadap Kualitas Laporan Keuangan Daerah. Institutional Repositories \& Scientific Journals.

Rudy. (2013). Analisis Tingkat Pengungkapan Laporan Tahunan Setelah Penerapan PSAK Berbasis IFRS (Studi Empiris pada Perusahaan Manufaktur di Bursa Efek Indonesia). Jurnal Ilmiah Gema Ekonomi, 4(1), 489-504.

Shintia, Cok Istri Agung Prami., \& Erawati, N. M. A. (2017). Pengaruh Kualitas SDM, Sistem Informasi, Pengendalian Intern dan Komitmen Organisasi pada Kualitas Laporan Keuangan. E-Jurnal Akuntansi Universitas Udayana, 21, 1186-1205.

Spathis, Ch., M. Doumpos., \& C. Z. (2002). Detecting Falsified Financial Statements: A Comparative Study using Multicriteria Analysis and Multivariate Statistical Techniques. European Accounting Review, 11(3), 509-535. https://doi.org/10.1080/0963818022000000966

Sukmaningrum, T. (2012). Analisis Fator-faktor yang Mempengaruhi Kualitas Informasi Laporan Keuangan Pemerintah Daerah (Studi Empiris pada Pemerintah Kabupaten dan Kota Semarang). Jurnal Akuntansi Universitas Diponegoro.

Trisnawati, Ni Nyoman., \& Wiratmaja, D. N. (2018). Pengaruh Kualitas Sumber Daya Manusia dan Sistem Pengendalian Intern Pada Kualitas Laporan Keuangan Pemerintah Daerah. E-Jurnal Akuntansi Universitas Udayana, 24(1), 768-792.

Yang, M Rayindha Prasatya., \& Suartana, I. W. (2017). Pengaruh Good Governance, Pengelolaan Keuangan Daerah dan Sistem pengendalian Intern Pemerintah pada Kinerja Pemerintah Daerah. E-Jurnal Akuntansi Universitas Udayana, 21(2), 1346-1372. 